\title{
EVALUATION OF CHANGES IN HOUSING CONDITIONS THROUGHOUT THE POLISH RURAL AREAS USING METHODS OF RELATIVE TAXONOMY
}

\author{
Romana Glowicka-Woloszyn ${ }^{1}$, Ph.D.; Agnieszka Kozera ${ }^{2}$, Ph.D.; \\ Joanna Stanislawska ${ }^{3}$, Ph.D.; Andrzej Woloszyn ${ }^{4}$, M.Sc. and Anna Rosa ${ }^{5,}$ Ph.D. \\ 1,2,3,4 Poznan University of Life Sciences; ${ }^{5}$ Institute of Rural and Agriculture Development, Polish Academy \\ of Sciences
}

\begin{abstract}
The aim of the article was to assess housing conditions of population in rural areas in the provinces in Poland in the years 2007-2016 and to analyse changes taking place in this period and the scale of disproportions between regions. The research was dynamic and concerned the verification of the research hypothesis assuming that the level of housing conditions of the population in rural areas in Poland in the voivodship system is equalizing. In order to assess the level and changes of the studied complex phenomenon, one of the relative taxonomy methods was used, in dynamic terms, which is based on the construction of a medium-based synthetic meter. This method not only allows you to classify units in a given period but above all, it allows to observe changes in the value of a synthetic variable over time, wherein the construction of a synthetic feature is based on the relativistic values of diagnostic features. The research was based on data from the Local Data Bank of the Central Statistical Office in Poland.

Only in the group of provinces where housing conditions in rural areas at the beginning of the research period (in 2004) were assessed as high compared to other provinces (relative class I) some convergence in the studied phenomenon in 2004-2016 was observed. Among 8 provinces, which in 2004 were characterized by a relatively low and average lower level of housing conditions in rural areas (relative classes II and III), we can talk about increasing the disproportions within the classes distinguished in 2004-2016. At the same time, however, the synthetic assessment of housing conditions in 5 provinces from classes II and III improved and approached the level of provinces from class I in the analyzed period and only only in 3 provinces this rating has deteriorated. The results of the research allowed only a partial confirmation of the research hypothesis.
\end{abstract}

Key words: housing conditions, relative taxonomy, rural areas, provinces, Poland. JEL code: $018, \mathrm{C} 38$,

\section{Introduction}

The significant differences in the socio-economic development and, consequently, in the standard of living of the population of countries and regions is one of the basic problems of the modern European economy. An important goal of the cohesion policy implemented in the EU is to equalize the standard of living and to reduce development disparities between regions. The living standards of the population, especially due to their important role in the life of every individual and family, are particularly evident in housing conditions. They can be considered in quantitative terms, indicating, for example, the availability of housing (existing housing stock), their features (area, number of rooms) and quality, i.e., for example, their equipment in technical infrastructure (water supply, sewage system, gas network etc.). The house, besides satisfying physiological needs, lying in the base Maslow's hierarchy of needs, is also a mean to fulfill all higher-level needs (security, belonging, recognition, self-fulfillment).

The importance of housing conditions for the life of the individual and the functioning of societies has been emphasized in many acts of global and EU range. European integration affects, to a large extent, the housing policies of member countries (Salamon, Muziol-Wieclawowicz 2015). According to art. II-94 paragraph 3 of Treaty establishing a Constitution for Europe (2005, p. 54) in order to counteract social exclusion and poverty, the EU recognizes and respects the right to social assistance and housing assistance, in accordance with the rules laid down in EU law and national laws and practices, to ensure a decent existence for all those who lack sufficient resources. As emphasized in the study prepared by EUROSTAT (Living Conditions in Europe 2014):"Poor 
housing conditions is an important barrier for achieving a standard of living considered as acceptable in the society".

Problems related to housing are also an important social problem in Poland. They concern both shortages in the scope of housing resources (due to the delay in construction in relation to the needs of the population) as well as housing equipment (Murawska, Gotowska, 2014, Kozera et al., 2017). The distribution of housing resources, their equipment in technical and sanitary facilities, and the needs of the society in terms of housing conditions are determined by, among others, the level of social and host development of the region, the demographic situation and changes in it, such as the level of migration, changes in the demographic structure.

In recent years, especially after Poland's accession to the European Union, rural areas are becoming more often the target of interest. Many attention is paid to their problems, prospects and development risks (Hadynski 2015; Heffner, Klemens 2016). This interest is dictated by the fact that, according to the methodology of distinguishing rural areas used by the Central Statistical Office, they occupy over $90 \%$ of Poland's area. The demographic potential of these areas, especially those close to larger urban centres, is also growing. In 2016, rural areas in Poland were inhabited by more than 15 million people, or $40 \%$ of the total population (Local Data Bank, access: 15.01 .2018$)$. As it results from the report Polska wies 2016, the most important indicators between the city and the countryside are characterized by the level of socio-economic development, as well as consumption patterns, demographic situation and many others. However, rural areas in Poland are still highly diversified on a regional basis in terms of the level of socioeconomic development and, as a result, in terms of housing conditions and the standard of living of the population (Murawska, Gotowska, 2014, Murawska 2012). The issues of measuring the level of housing conditions of the population in rural areas in the regional system (provinces) is therefore extremely important from an economic, social and political point of view. This information is necessary for the implementation of the national regional development policy, as well as for the implementation of the cohesion policy objectives.

The aim of the article was to assess housing conditions of population in rural areas in the provinces in Poland in the years 2007-2016 and to analyse changes taking place in this period and the scale of disproportions between regions. The research was dynamic and concerned the verification of a research hypothesis assuming that the level of housing conditions of the population in rural areas in Poland in the system of voivodeships is balanced. This aim was achieved by a research task that involved construction of a synthetic index of housing conditions using one of the methods of dynamic relative taxonomy. This method not only allows to classify units in a given period, but above all enables observation of changes in the value of a synthetic variable over time, wherein the structure of a synthetic feature is based on the relativistic values of diagnostic features. The research was based on data from the Local Data Bank of the Central Statistical Office in Poland.

\section{Research methodology}

Housing conditions are a multidimensional phenomenon, they are examined usually using taxonomic methods (Kozera, 2016; Kozera, 2017). Among the applied research approaches, the methods of constructing a synthetic meter are often used. On the basis of the obtained values of the synthetic meter, the examined objects are sorted (eg regions) and their ranking is created. According to Wydymus (2013), the determination of the relative position of a given region (e.g. 
country, province) on this basis is highly problematic. In this situation, a relative taxonomy can be used to synthetically assess housing conditions, in which no particular simple features are considered, but rather relativized indicators, which in terms of individual features are designated as quotients of the trait value in a given region in relation to the values of other regions (Wydymus, 2013).

To assess housing conditions in rural areas in terms of voivodships in Poland in the years 20042016, the following diagnostic features (stimulants) were selected:

$\mathrm{X} 1$ - the number of housing units in rural areas per 1 thousand residents,

X2 - average usable floor area of a housing unit per one person in rural areas (sq.m.),

X3 - percentage of rural population using the water supply network ( \%),

$\mathrm{X} 4$ - percentage of rural population using the sewage network $(\%)$,

X5 - percentage of housing units equipped with a toilet flushed with water (\%),

X6 - percentage of housing units equipped with bathroom ( \%),

$X 7$ - percentage of rural population using the gas network $(\%)$,

$\mathrm{X} 8$ - percentage of housing units equipped with central heating ( $\%)$.

To determine the relative value of a synthetic measure of housing conditions in rural areas in Polish voivodships in particular years in the period of 2004-2016, the procedure described by Wydymus (2013) was used, which was also used in other studies (Lira et al., 2014; Lira 2015).

The values of individual features (housing conditions) for each object (province) and each year were relativized according to the formula (Wydymus 2013):

$$
d_{(b) j t}=\frac{x_{b j t}}{x_{c j t}}
$$

where: $b \neq c, b=1, \ldots, n, c=1, \ldots, n$

$x_{i j t}$ - denoted the observation in the $i$-th province $(i=1, \ldots, n)$ of the $j$-th housing conditions $(j=1, \ldots, m)$ in year $\mathrm{t}(t=1, \ldots, k)$.

Thus transformed housing conditions indices of the $c$-th province relative to other province for feature $j$ and year $t$ could be presented in the following form (Wydymus 2013):

$$
\mathbf{D}_{j t}=\left[\begin{array}{cccc}
1 & d_{\left(\frac{2}{1}\right) j t} & & d_{\left(\frac{\mathbf{n}}{1}\right) j t} \\
d_{\left(\frac{1}{2}\right) j t} & 1 & & d_{\left(\frac{\mathbf{n}}{2}\right) j t} \\
& \vdots & \ddots & \vdots \\
d_{\left(\frac{1}{\mathbf{n}}\right) j t} & d_{\left(\frac{2}{\mathbf{n}}\right) j t} & \cdots & 1
\end{array}\right]
$$

In order to classify the objects with respect to all diagnostic features simultaneously the subsequent matrices were calculated (Wydymus, 2013):

$$
\mathbf{D}_{j t}^{*}=\mathbf{A} \cdot \mathbf{D}_{j t}
$$

where the matrix $\mathbf{A}$ was defined as:

$$
\mathbf{A}=\left[\begin{array}{ccc}
0 & \cdots & \frac{1}{(m-1)} \\
\vdots & \ddots & \vdots \\
\frac{1}{(m-1)} & \cdots & 0
\end{array}\right]
$$

The diagonal elements of $\mathbf{D}_{j t}^{*}$ formed matrices $\mathbf{W}_{t}$ (for each time period): 


$$
\mathbf{W}_{t}=\left[\begin{array}{cccc}
W_{11 t} & W_{12 t} & \cdots & w_{1 m t} \\
W_{21 t} & w_{22 t} & \cdots & w_{2 m t} \\
\vdots & \vdots & \ddots & \vdots \\
w_{n 1 t} & w_{n 2 t} & \cdots & w_{n m t}
\end{array}\right]
$$

The higher the value of $\mathrm{W}_{\mathrm{ijt}}$ index, the greater was the advantage of the $\mathrm{i}$-th province over remaining ones in the $\mathrm{j}$-th feature (housing conditions) and in the $\mathrm{t}$-th year.

Next, the $\mathbf{W}_{t}$ matrices were used to compute the $S_{i t}$ matrix of relative synthetic indices of development for given objects and time periods (Wydymus, 2013):

$$
\mathrm{S}_{i t}=\frac{1}{m} \sum_{j} \frac{1}{w_{i j t}} \quad \text { (6) }
$$

The values of $S_{i t}$ smaller than 1 signified relative advantage of the $\mathrm{i}$-th object over others in period $t$.

The research drew on data from Local Data Bank published by the Central Statistical Office in Warsaw. Calculations were performed in R.

\section{Research results and discussion}

Values of the relative synthetic index $\left(S_{i t}\right)$ of housing conditions in rural areas calculated for 2004 period were used for linear ordering of the provinces: from the highest values of the index to the lowest. Next, the differences between adjacent provinces were computed and used to classify all the provinces into three typological classes. The decision to split a class was made when the differences came out relatively high. Class I of high relative housing conditions level in rural areas in 2004 comprised the provinces of Dolnoslaskie, Lubuskie, Malopolskie, Podkarpackie, Pomorskie, Slaskie, Wielkopolskie, Zachodniopomorskie, and class II of medium low relative level: Lubelskie, Mazowieckie, Opolskie, Swietokrzyskie and Warminsko-Mazurskie, class III of low relative level and, and class IV of low relative level: Kujawsko-Pomorskie, Lodzkie, Podlaskie.

The voivodships in which the housing conditions in rural areas in 2004 compared to all other voivodeships were clearly better were qualified to the relative class I (the synthetic relative index in 2004 reached values below 1). In this class, there were three voivodeships, namely Pomorskie, Malopolskie and Lubuskie, where in the period 2004-2016 further improvement of housing conditions was noted in comparison to other voivodships (Table 2). This was confirmed by the decreases in the value of the synthetic index between 2004 and 2016. It can be assumed that these voivodships strengthened their position of leaders in the considered period - voivodships with the highest assessment of housing conditions in rural areas. Analyzing the values of changes in the relative synthetic index between 2004 and 2016, in the case of the Pomorskie Voivodship one can speak of moderate improvement (decrease in the value of the $S_{i t}$ indicator by $1.35 \%$ ) and in the case of the other two voivodeships (Malopolskie and Lubuskie) with slight improvement (changes in the value of the indicator were $-0.67 \%$ and $-0.11 \%$ respectively). In the case of five voivodships from class I located in the western and southern parts of Poland, i.e. Zachodniopomorskie, Wielkopolskie, Dolnoslaskie, Slaskie and Podkarpackie, a slight deterioration of the relative assessment of housing conditions was recorded in 2004-2016 (slight increase in the value of the $S_{i t}$ meter). However, this situation did not result from the deterioration of housing conditions in reality, but from the more dynamic improvement of conditions in other voivodships, for which they were compared. In the case of these voivodships, one can therefore speak of a relative weakening of the position of leaders in terms of housing conditions in rural areas. By far the most weakened 
position of the Slaskie Voivodeship in 2004-2016 (increase in the value of the synthetic reference rate by $6.21 \%$ ), which in 2004 was in the first place in terms of the assessment of housing conditions in rural areas (the value of the $S_{i t}$ indicator was 0.78 ).

Values of relative synthetic index $S_{i t}$ of housing conditions in rural areas for all Polish provinces in 2004-2016

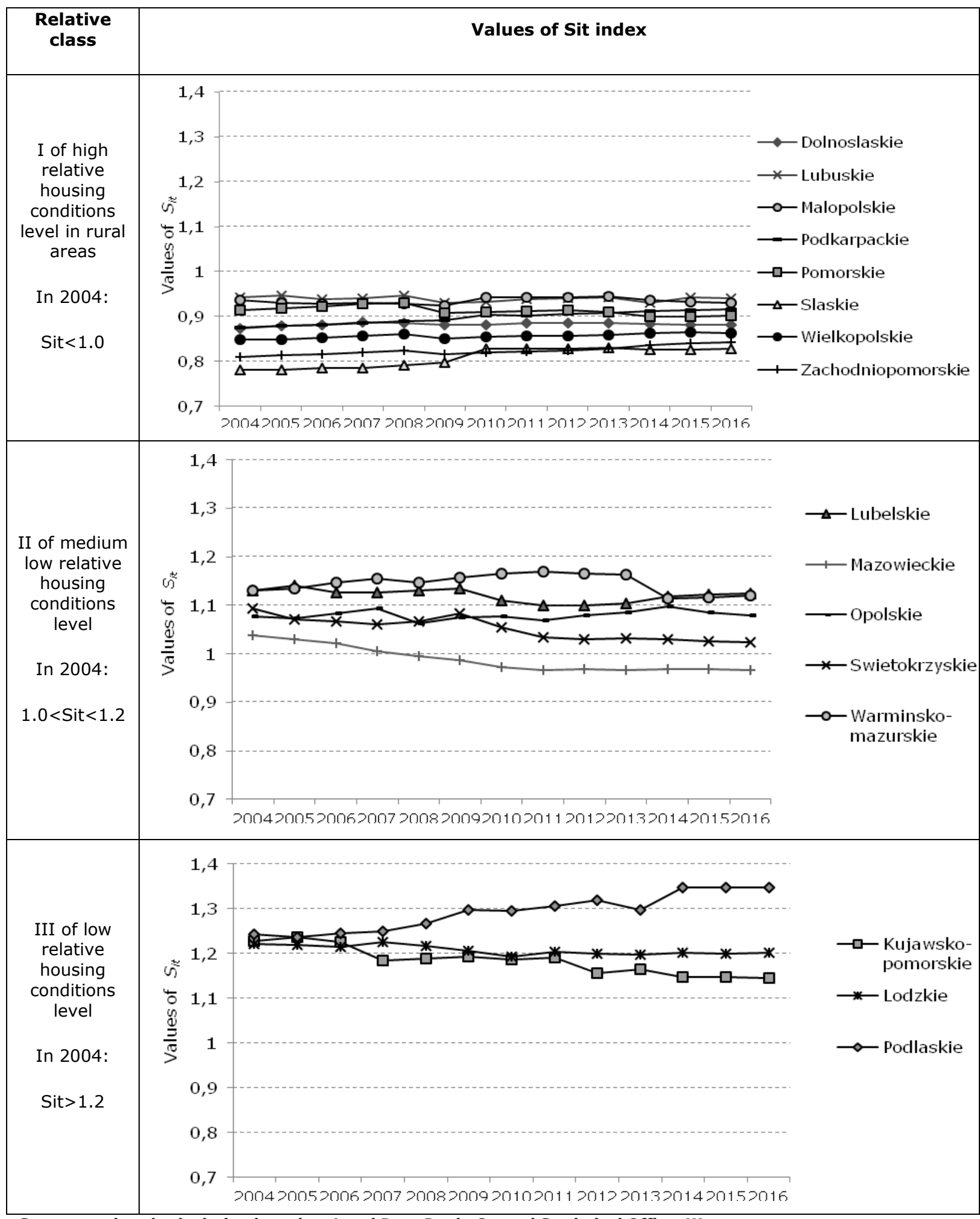

Source: authors' calculation based on Local Data Bank, Central Statistical Office, Warsaw 
Values of relative synthetic index $S_{i t}$ of housing conditions in rural areas for all Polish provinces in 2004-2016 and evaluation of its change between 2004 and 2016

\begin{tabular}{|c|c|c|c|c|c|c|c|c|c|c|c|c|c|c|c|c|c|}
\hline \multirow[b]{2}{*}{$\begin{array}{l}\text { Relative } \\
\text { class }\end{array}$} & \multirow{2}{*}{\multicolumn{2}{|c|}{$\begin{array}{l}\text { Relative change in relation to other } \\
\text { provinces }\end{array}$}} & \multirow[b]{2}{*}{ Provinces } & \multicolumn{13}{|c|}{ Years } & \multirow{2}{*}{$\begin{array}{c}\text { Change of } \\
\text { values of } S_{i} \\
2016 / 2004 \\
(\%)^{*}\end{array}$} \\
\hline & & & & ষ্ণ & ᄂ & $\stackrel{0}{0}$ & ô & $\stackrel{\infty}{\circ}$ & : & ํ. & $\stackrel{-1}{-1}$ & บับ & $\stackrel{m}{0}$ & $\stackrel{\substack{0\\
}}{\pi}$ & $\stackrel{n}{0}$ & $\stackrel{0}{0}$ & \\
\hline \multirow{8}{*}{ 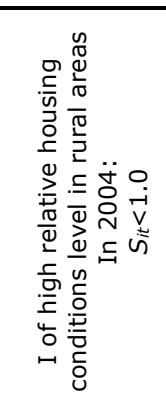 } & \multirow{3}{*}{$\begin{array}{l}\text { relative } \\
\text { improvement - } \\
\text { strengthened } \\
\text { position of } \\
\text { leaders } \\
\end{array}$} & $\begin{array}{l}\text { moderate improvement } \\
\left(-5 \%<S_{i t}<-1 \%\right)\end{array}$ & Pomorskie & 0.91 & 0.92 & 0.92 & 0.93 & 0.93 & 0.91 & 0.91 & 0.91 & 0.91 & 0.91 & 0.9 & 0.9 & 0.9 & -1.35 \\
\hline & & \multirow{2}{*}{$\begin{array}{l}\text { slight improvement } \\
\left(-1 \%<S_{i t}<0 \%\right)\end{array}$} & Malopolskie & 0.94 & 0.93 & 0.93 & 0.93 & 0.93 & 0.93 & 0.94 & 0.94 & 0.94 & 0.94 & 0.94 & 0.93 & 0.93 & -0.67 \\
\hline & & & Lubuskie & 0.94 & 0.95 & 0.94 & 0.94 & 0.95 & 0.93 & 0.93 & 0.94 & 0.94 & 0.94 & 0.93 & 0.94 & 0.94 & -0.11 \\
\hline & \multirow{5}{*}{$\begin{array}{l}\text { relative } \\
\text { deterioration - } \\
\text { weakening of the } \\
\text { position of } \\
\text { leaders }\end{array}$} & $\begin{array}{l}\text { slight deterioration } \\
\left(0 \%<S_{i t}<1 \%\right)\end{array}$ & Dolnoslaskie & 0.87 & 0.88 & 0.88 & 0.89 & 0.89 & 0.88 & 0.88 & 0.88 & 0.89 & 0.89 & 0.88 & 0.88 & 0.88 & 0.82 \\
\hline & & \multirow{3}{*}{$\begin{array}{l}\text { moderate deterioration } \\
\left(1 \%<S_{\text {it }}<5 \%\right)\end{array}$} & Wielkopolskie & 0.85 & 0.85 & 0.85 & 0.86 & 0.86 & 0.85 & 0.85 & 0.86 & 0.86 & 0.86 & 0.86 & 0.86 & 0.86 & 1.85 \\
\hline & & & $\begin{array}{l}\text { Zachodnio- } \\
\text { pomorskie }\end{array}$ & 0.81 & 0.81 & 0.82 & 0.82 & 0.82 & 0.82 & 0.82 & 0.82 & 0.83 & 0.83 & 0.84 & 0.84 & 0.84 & 3.86 \\
\hline & & & Podkarpackie & 0.88 & 0.88 & 0.88 & 0.89 & 0.89 & 0.89 & 0.9 & 0.9 & 0.91 & 0.91 & 0.91 & 0.91 & 0.92 & 4.67 \\
\hline & & $\begin{array}{l}\text { appreciable } \\
\text { deterioration }\left(S_{i t}>5 \%\right)\end{array}$ & Slaskie & 0.78 & 0.78 & 0.78 & 0.79 & 0.79 & 0.8 & 0.83 & 0.83 & 0.83 & 0.83 & 0.83 & 0.83 & 0.83 & 6.21 \\
\hline \multirow{5}{*}{ 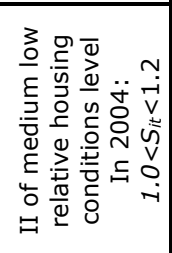 } & \multirow{4}{*}{$\begin{array}{l}\text { relative } \\
\text { improvement }\end{array}$} & \multirow{2}{*}{$\begin{array}{l}\text { appreciable } \\
\text { improvement } \\
\left(S_{i t}<-5 \%\right)\end{array}$} & Mazowieckie & 1.04 & 1.03 & 1.02 & 1 & 0.99 & 0.99 & 0.97 & 0.97 & 0.97 & 0.97 & 0.97 & 0.97 & 0.97 & -6.92 \\
\hline & & & Swietokrzyskie & 1.09 & 1.07 & 1.07 & 1.06 & 1.07 & 1.08 & 1.05 & 1.03 & 1.03 & 1.03 & 1.03 & 1.03 & 1.03 & -6.32 \\
\hline & & \multirow{2}{*}{$\begin{array}{l}\text { slight improvement } \\
\left(-1 \%<S_{i t}<0 \%\right)\end{array}$} & $\begin{array}{l}\text { Warminsko- } \\
\text { mazurskie }\end{array}$ & 1.13 & 1.14 & 1.15 & 1.15 & 1.15 & 1.16 & 1.17 & 1.17 & 1.17 & 1.16 & 1.12 & 1.12 & 1.12 & -0.9 \\
\hline & & & Lubelskie & 1.13 & 1.14 & 1.13 & 1.13 & 1.13 & 1.14 & 1.11 & 1.1 & 1.1 & 1.1 & 1.12 & 1.12 & 1.13 & -0.43 \\
\hline & $\begin{array}{l}\text { relative } \\
\text { deterioration }\end{array}$ & $\begin{array}{l}\text { slight deterioration } \\
\left(0 \%<S_{i t}<1 \%\right)\end{array}$ & Opolskie & 1.08 & 1.07 & 1.08 & 1.09 & 1.06 & 1.08 & 1.08 & 1.07 & 1.08 & 1.09 & 1.1 & 1.09 & 1.08 & 0.31 \\
\hline \multirow{3}{*}{ 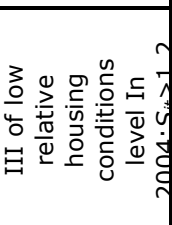 } & \multirow{2}{*}{$\begin{array}{l}\text { relative } \\
\text { improvement }\end{array}$} & $\begin{array}{l}\text { significant improvement } \\
\left(S_{i t}<-5 \%\right)\end{array}$ & $\begin{array}{l}\text { Kujawsko- } \\
\text { pomorskie }\end{array}$ & 1.23 & 1.24 & 1.23 & 1.18 & 1.19 & 1.19 & 1.19 & 1.19 & 1.16 & 1.16 & 1.15 & 1.15 & 1.15 & -6.7 \\
\hline & & $\begin{array}{l}\text { moderate improvement } \\
\left(-5 \%<S_{i t}<-1 \%\right)\end{array}$ & Lodzkie & 1.22 & 1.22 & 1.21 & 1.23 & 1.22 & 1.21 & 1.19 & 1.2 & 1.2 & 1.2 & 1.2 & 1.2 & 1.2 & -1.65 \\
\hline & $\begin{array}{l}\text { relative } \\
\text { deterioration }\end{array}$ & $\begin{array}{l}\text { significant deterioration } \\
\left(S_{i t}>5 \%\right)\end{array}$ & Podlaskie & 1.24 & 1.24 & 1.25 & 1.25 & 1.27 & 1.3 & 1.3 & 1.31 & 1.32 & 1.3 & 1.35 & 1.35 & 1.35 & 8.46 \\
\hline \multicolumn{4}{|c|}{ The range of the index $S_{i t}$ value } & 0.46 & 0.45 & 0.46 & 0.46 & 0.48 & 0.5 & 0.48 & 0.48 & 0.49 & 0.47 & 0.52 & 0.52 & 0.52 & - \\
\hline
\end{tabular}

Source: authors' calculation based on Local Data Bank, Central Statistical Office, Warsaw 
To the relative class II (Table 1), voivodships, in which housing conditions were rated as lower average in comparison to other voivodships (the relative synthetic value ranging from 1.04 to 1.13), were classified. In this class of voivodships there were voivodships: Lubelskie, Mazowieckie, Opolskie, Swietokrzyskie and Warminsko-mazurskie. Of the five voivodships in this class, in as many as four, in 2004-2016, the improvement of housing conditions was noted, whereas in the Mazowieckie and Swietokrzyskie voivodships, the improvement was appreciable (the decrease of $S_{i t}$ indicator by more than $6 \%$ ) and in Lubelskie and Warminsko-mazurskie - insignificant (the decrease of $S_{i t}$ indicator by less than $1 \%$ ). However, in the Opolskie Voivodeship, there was a slight deterioration of housing conditions in rural areas in the considered period.

In 2004, three provinces: Kujawsko-Pomorskie, Lodzkie and Podlaskie were characterized by a low relative assessment of housing conditions in rural areas. In the years 2004-2016, a significant improvement in terms of housing conditions was noted in the Kujawsko-Pomorskie Province (the decrease of $S_{i t}$ indicator by $6.7 \%$ ) and in the Lodzkie region - moderate improvement (the decrease by $1.65 \%$ ). In the least favourable situation were rural areas in the Podlaskie Province, because in 2004 this voivodship was on the last position in the voivodship ranking in terms of assessing housing conditions in rural areas (the value of the relative synthetic index was 1.24) and in the considered period there was a further significant deterioration of this assessment (increase in the value of the $S_{i t}$ indicator by 8.46 - it was the highest recorded increase of the $S_{i t}$ index).

From the construction of a relative synthetic measure used in the study it appears that voivodships would not differ in terms of the assessment of the studied phenomenon, if the value of this indicator for all voivodeships was equal 1 . Analysing the values of $S_{i t}$ indicator in individual years, it was found that only in class I, with a relatively high assessment of housing conditions in rural areas in 2004, a slight reduction in the disproportions in the studied phenomenon in 20042016 was noted. The range of values of the $S_{i t}$ indicator, which in 2004 ranged from 0.78 to 0.94 decreased to the range from 0.83 to 0.94 (Table 2 and Table 1).

In relative class II and III, however, there was a marked increase in disproportions, which is clearly presented in the figures in Table 1 . The values of the relative synthetic index of housing conditions in rural areas in 2004 for all voivodships ranged from 0.78 (Slaskie) to 1.24 (Podlaskie Voivodeship), so their spread was 0.46 (Table 2). The values of the indicator in 2016, however, ranged from 0.83 to 1.35 (the spread was 0.52 ). The increase in the spread of the $S_{i t}$ indicator between 2004 and 2016 shows an increase in the disproportion between voivodships in terms of housing conditions in rural areas. At the same time, for five provinces from these classes (Mazowieckie, Swietokrzyskie, Warminsko-mazurskie, Lubelskie, Kujawsko-Pomorskie and Lodzkie) improvement in housing conditions was observed, and a synthetic assessment of their level approached the assessment of housing conditions in Class I. Only in three voivodships deterioration of the relative synthetic evaluation of the studied phenomenon and, as a result, increase in the spread of the indicator value $S_{i t}$ was observed.

The conducted empirical research allowed only a partial verification of the research hypothesis assuming that "the level of housing conditions in rural areas in Poland in the system of provinces is levelling out", as only in 13 out of 16 provinces, convergence in the studied phenomenon was observed. 


\section{Conclusions, proposals, recommendations}

1) The use of a relative synthetic indicator to assess housing conditions in rural areas in the Polish provinces allowed not only to assess the level of the studied phenomenon in each region in relation to other regions, but also to analyse changes in the relative level of housing conditions in the 2004-2016 period.

2) For $50 \%$ of provinces, housing conditions at the beginning of the research period (in 2004) were assessed as high compared to other provinces, and in the second half of the voivodeships as average lower and lower. While awaiting the convergence processes and reducing disparities between regions, convergence in the subsequent years of the relative values of indicators to unity should be expected. This would mean reducing the advantage (relative "deterioration") in terms of housing conditions in class I (i.e., the increase in the value of a relative synthetic index) and a relative improvement in the assessment of housing conditions in class II and III. Unfortunately, while in class I a convergence in the field of the studied phenomenon was observed, in the class II and III we can talk about increasing disproportions between voivodships in terms of housing conditions in rural areas.

3) Due to the fact that the distribution of the housing resources, their equipment in technical and sanitary facilities is related to both the economic and demographic situation of the regions, it is advisable to continue the undertaken research and link these phenomena, which would enable identification of conditions for improving housing conditions voivodships in Poland.

\section{Bibliography}

1. Bank Danych Lokalnych (Local Data Bank), Glowny Urzad Statystyczny (Central Statistical Office), Retrieved: http://www.stat.gov.pl/bdl. Access: 15.12.2017.

2. Szymanska, D. and Bieganska, J., 2012: Infrastructure's and Housing's Development in the Rural Areas in Poland - Some Problems. In: Journal of Infrastructure Development, Vol. 4, No. 1, SAGE: Los Angeles, London, New Delhi, Singapore, Washington DC, pp. 1-17. DOI: 10.1177/0974930612449533.

3. Dolata M., Lira J. (2015). Relatywne zmiany poziomu zasobow mieszkaniowych i wyposazenia technicznosanitarnego mieszkan na obszarach wiejskich wojewodztwa wielkopolskiego (The Relative Changes in the Level of Housing stock and Equipment Technical and Sanitary Housing in Rural Areas of the Wielkopolska Voivodship). Wiadomosci Statystyczne, 10 (677), pp. 52-68.

4. Hadynski, J. (2015). Regionalna konkurencyjnosc obszarow wiejskich (Regional Competitiveness of Rural Areas). Wydawnictwo Uniwersytetu Przyrodniczego w Poznaniu, Poznan.

5. Heffner, K., Klemens, B. (ed.) (2016). Obszary wiejskie: wiejska przestrzen i ludnosc, aktywnosc spoleczna $i$ przedsiebiorczosc (Rural Areas: Rural Space and Population, Social Activity and Entrepreneurship). Komitet Przestrzennego Zagospodarowania Kraju PAN, Warszawa.

6. Kozera A. (2016). A taxonomic Analysis of Housing Poverty in the European Union, In Karlovitz J.T. (ed.) "Some studies of economic changes", International Research Institute, Komarno, pp. 63-72.

7. Kozera A., Stanislawska J., Glowicka-Woloszyn R. (2017). Zjawisko ubostwa mieszkaniowego w krajach Unii Europejskiej (The Occurrence of Housing Poverty in the European Union), Wiadomosci Statystyczne, no. 1 (668) 2017, pp. 77-89.

8. Lira J., Glowicka-Woloszyn R., Woloszyn A. (2014). The Application of Relative Taxonomy Methods to the Study of Technical Infrastructure Development in Rural Areas Across the Provinces of Poland, Quantitative Methods in Economics, vol. 15, no. 2, pp. 330-338.

9. Living Conditions in Europe (2014), EUROSTAT, Retrieved: http://ec.europa.eu/eurostat/documents/3217494/ 6303711/KS-DZ-14-001-EN-N.pdf/d867b24b-da98427d-bca2-d8bc212ff7a8. Access: 15.12.2017.

10. Murawska A. (2012). Zmiany w poziomie i jakosci zycia ludnosci na obszarach wiejskich w Polsce (Changes in the Level and Quality of Life of the Rural Population in Poland). Journal of Agribusiness and Rural Development, 3(25), pp. 169-180.

11. Murawska A., Gotowska M. (2014). Regional Differences in the Level and Quality of Housing Conditions Among Polish Households. Oeconomia, 13 (2), pp. 105-115.

12. Raport o stanie wsi - Polska wies 2016 (Report on the State of the Village - Polish village 2016) (2016). Wilkin J., Nurzynska I. (ed.). Fundacja na Rzecz Rozwoju Polskiego Rolnictwa, Wydawnictwo Naukowe Scholar. Warszawa 
Proceedings of the 2018 International Conference "ECONOMIC SCIENCE FOR RURAL DEVELOPMENT" No 49

Jelgava, LLU ESAF, 911 May 2018, pp. 232-240

DOI 10.22616/ESRD.2018.140

13. Salamon, M., Muziol-Wieclawowicz, A. (2015). Mieszkalnictwo w Polsce (Housing in Poland), Habitat for Humanity Poland, (www.forummieszkaniowe.org/files/Mieszkalnictwo_w_Polsce_2015_HaBitat.pdf, access: 15.01.2018).

14. Unia Europejska, 2005: Traktat ustanawiajacy Konstytucje dla Europy, Urzad Oficjalnych Publikacji Wspolnot Europejskich, Luksemburg, https://europa.eu/europeanunion/sites/europaeu/files/docs/body/treaty_establishing_a_constitution_for_europe_pl.pdf, access: 15.01.2018).

15. Wydymus, S. (2013). Rozwoj gospodarczy a poziom wynagrodzen w krajach Unii Europejskiej - analiza taksonomiczna (Economic Development and Income Level in EU Countries - Taxonomic Analysis). Finanse, Rynki Finansowe, Ubezpieczenia, vol. 57, pp. 631-645. 